\section{Autohemotherapy increases phagocytic activity of neutrophils and promotes cytokine production by lymphocytes in horses}

\author{
Auto-hemoterapia aumenta a atividade fagocítica dos \\ neutrófilos e promove a produção de citocinas pelos linfócitos \\ em cavalos
}

\author{
Paula Rodrigues Lopes' ${ }^{1}$ Mauricio Azevedo Batista², Rodrigo Pedro Soares², Jéssica Guerra de Oliveira', \\ Fabiola de Oliveira Paes Leme ${ }^{3}$, Olindo Assis Martins-Filho², Renata de Pino Albuquerque Maranhão ${ }^{4}$, \\ Raphael Rocha Wenceslau ${ }^{5}$, Maristela Silveira Palhares ${ }^{4}$ \& Marcio Sobreira Silva Araújo ${ }^{2 *}$ \\ 'Veterinarian, Laboratório de Ensino Pesquisa e Extensão em equídeos de tração (LEPET), Escola de Veterinária, Universidade \\ Federal de Minas Gerais (UFMG), Belo Horizonte, MG, Brazil. \\ ²Biologist, DSc., Instituto René Rachou, Fundação Oswaldo Cruz, Belo Horizonte, MG, Brazil. \\ ${ }^{3}$ Veterinarian, DSc., Laboratório de Análises Clínicas, Escola de Veterinária, UFMG, Belo Horizonte, MG, Brasil. \\ ${ }^{4}$ Veterinarian, DSc., LEPET, Escola de Veterinária, UFMG, Belo Horizonte, MG, Brazil. \\ ${ }^{5}$ Veterinarian, DSc., Departamento de Clínica e Cirurgia veterinárias, Escola de Veterinária, UFMG, Belo Horizonte, MG, Brazil.
}

\begin{abstract}
Autohemotherapy (AHT) is a procedure in which blood is collected by venipuncture, followed by immediate reinjection to activate an animal's immune system. In this preliminary study, we evaluated the effect of AHT on clinical, hematological and biochemical parameters and immune responses in horses. Eight healthy animals (four males and four females) were clinically evaluated and subjected to AHT (three applications at a weekly interval). Blood samples were collected before AHT (TO) and $3 \mathrm{~d}$ after each procedure (T1, T2, and T3). AHT did not affect most clinical, biochemical, and hematological parameters in the test animals. However, flow cytometry detected an increase in Tlymphocytes (CD3 ${ }^{+}$) and cytokine production (IFN- $\gamma$, IL-1O, IL-4, and IL-6). In addition, AHT stimulated phagocytosis by neutrophils at T3. Although preliminary, our results suggest that AHT is a promising procedure for equine management, as AHT was found to stimulate the horses' immune responses without affecting their general status.
\end{abstract}

Keywords: autohemotherapy, horse, cytokines, phagocytosis.

\section{Resumo}

A auto-hemoterapia (AHT) é um procedimento em que o sangue é coletado por punção venosa, seguida de imediata reinjeção, com o objetivo de ativar o sistema imunológico do animal. O objetivo deste estudo preliminar foi avaliar o impacto do AHT nos parâmetros clínicos, hematológicos, bioquímicos e de respostas imunológicas em cavalos. Oito animais saudáveis (4 machos e 4 fêmeas) foram avaliados clinicamente e submetidos a AHT ( 3 aplicações, com intervalo de uma semana). O sangue foi coletado antes do AHT (TO) e 3 dias após cada procedimento (T1, T2 e T3). Em geral, o AHT não afetou consideravelmente os parâmetros clínicos, bioquímicos e hematológicos dos cavalos. No entanto, as análises de citometria de fluxo detectaram um pico de linfócitos T (CD3+) e produção de citocinas (IFN- $\gamma$, IL-1O, IL-4 e IL-6) em T1 e T2. Além disso, o AHT estimulou a atividade de fagocitose nos neutrófilos, especialmente durante o T3. Embora preliminares, nossos resultados sugerem que a AHT pode ser procedimento promissor para o manejo de equinos. A AHT estimula a resposta imune sem afetar o estado geral do animal.

Palavras-chave: autohemoterapia, cavalo, citocinas, fagocitose.

\section{Introduction}

Autohemotherapy (AHT) was first reported in 1913 by doctors Ravaut and Spiethoff for treating dermatological diseases. It is a low-cost therapeutic practice where autologous whole blood or serum is injected intramuscularly or subcutaneously (Ravaut, 1913; Spiethoff, 1913). This procedure is believed to help in the treatment of several diseases (Brewer, 2014); however, mechanisms underlying most immune responses to AHT remain unclear (Borges et al., 2014). AHT is clinically effective in the treatment of various infectious and non-infectious human diseases, including fibromyalgia (Moreno-Fernández et al., 2019), urticaria (Sheikhi et al., 2014),
How to cite: Lopes, P. R., Batista, M. A., Soares, R. P., Oliveira, J. G., Leme, F. O. P., Martins-Filho, O A., Maranhão, R. P. A., Wenceslau, R. R., Palhares, M.S., \&Araújo, M. S. S. (2021). Autohemotherapy increases phagocytic activity of neutrophils and promotes cytokine production by lymphocytes in horses. Brazilian Journal of Veterinary Medicine, 43, e000821. https://doi.org/10.29374/25272179.bjvm000821

Received: March 03, 2021.

Accepted: May 17, 2021

\section{*Correspondence}

Marcio Sobreira Silva Araújo Instituto René Rachou, Fundação Oswaldo Cruz

Av. Augusto de Lima, 1715, Barro Preto CEP 30190-002 - Belo Horizonte (MG), Brasil E-mail:marcio.sobreira@fiocruz.br 
atherosclerotic ischemia (Tylicki et al., 2001), and herpes (Olwin et al., 1997). However, a lack of scientific studies hinder the adequate evaluation of the benefits and risks associated with AHT. In this context, studies are needed to ascertain the validity and efficacy of this alternative therapy not only in humans but also in animals (Webster et al., 2000).

The immune response mechanisms triggered by AHT remain unknown; however, it is known that the reinjection of bovine blood can promote non-specific protein stimulation due to erythrocyte degradation and the resulting products (Santin \& Brito, 2004). It has also been postulated that AHT modulates immune responses to autologous antigens, which are thought to be involved in histamine release from mast cells and basophils in humans (Sheikhi et al., 2014). In humans, early studies have shown that AHT leads to a decrease in circulating leukocytes because of their migration to tissues and abdominal organs, increasing their systemic function (Mettenleiter, 1936; Teixeira, 1940). A four-fold increase in the number of macrophages was detected in the wounds of patients who received AHT. However, after $5 \mathrm{~d}$, the macrophage numbers returned to baseline levels, indicating that AHT could be repeated at a 1-week interval (Teixeira, 1940). More recently, Trevisanil et al. (2015) observed that the number of monocytes and levels of the immunoglobulins IgM, IgG, and IgE increased in healthy human patients after a single dose of AHT, confirming the ability of AHT to stimulate an immune response.

In the veterinary field, AHT has yielded clinical benefits and therapeutic outcomes. For instance, in horses, AHT has caused a reduction in tumor mass (Thomassian, 2005) and facilitated the substitution of conventional protocols in the postoperative period of orchiectomy (Barnabé Escodro et al., 2012). In dogs, AHT is clinically effective against parvoviruses (Borges et al., 2014). AHT was developed over a century ago (Brewer, 2014); however, owing to the lack of substantial scientific evidence and access to sensitive techniques, AHT was discontinued for many years. In the past two decades, AHT has re-emerged as a potential alternative to treatment of some disease. As part of a broad study on AHT, we aimed to evaluate the safety and effects of this procedure in horses using conventional and sensitive techniques.

\section{Materials and methods}

\section{Animals and experimental design}

Eight healthy horses (four males and four females; five Haflinger and three non-defined breeds) with ages ranging from 2 to 4 years were maintained at the Veterinary Hospital at the Federal University of Minas Gerais (UFMG), Brazil. The animals belonged to the Veterinary school and received water and a balanced diet ad libitum. The horses were clinically evaluated prior to inclusion in the study. All procedures were performed according to the guidelines set by the Brazilian Animal Experimental College (COBEA). This study was approved by the Ethical Committee for the Use of Experimental Animals (CETEA) of the UFMG (protocol no. 351/2017).

\section{AHT}

In this study, the control group included animals before AHT (TO). These animals were then subjected to three applications of AHT at a weekly interval (T1, T2, and T3). Blood samples were collected, and the parameters before (TO) and after treatment (T1, T2, and T3) were compared. The AHT procedure was performed using three intramuscular doses using $20 \mathrm{~mL}$ syringes and $30 \times 0.08 \mathrm{~mm}$ needles per animal, with an interval of 1 week $(7 \mathrm{~d})$ between procedures. The total blood volume applied was calculated according to the animal's weight ( $20 \mathrm{~mL}$ peripheral blood per $100 \mathrm{~kg}$ weight). The average horse weight was $300.10 \pm 50.53 \mathrm{~kg}$. A maximum of $20 \mathrm{~mL}$ of whole peripheral blood (without anticoagulant use) was inoculated intramuscularly at each application site after careful antisepsis with 70\% ethanol. Depending on the volume injected, three to four sites were selected, including the serratus ventral muscles (neck musculature on the right and left sides) and semi tendinous and semimembranosus muscles (medial musculature of the right and left sides).

\section{Physical evaluation}

To determine the health status of the horses, physical examinations were performed by the same evaluator (P.R.L.) during all experimental procedures (before and after collecting/injecting 
blood). Physical examination included inspection, rectal temperature $\left({ }^{\circ} \mathrm{C}\right)$, capillary refill time (CRT; in s), heart rate (beats/min), respiratory rate (movements/min), pulse (heart rate/min), evaluation of mucous membranes and lymph nodes, auscultation of cardiac and respiratory foci, and abdominal auscultation.

\section{Blood samples}

Peripheral blood samples in EDTA (7 mL, hematological analysis), or heparin ( $7 \mathrm{~mL}$, immunological analysis), and without anticoagulant ( $7 \mathrm{~mL}$, biochemical analysis) were collected at four different times: before ATH (TO) and $3 \mathrm{~d}$ after the first, second, and third ATH procedures (T1, T2, and T3, respectively). Blood was obtained from the jugular vein after venipuncture using a $20 \mathrm{~mL}$ syringe (using a $40 \times 1.12 \mathrm{~mm}$ needle).

\section{Biochemical blood tests}

To evaluate the effect of AHT on serum proteins and liver and kidney enzymes, peripheral blood samples without anticoagulant were collected at TO, T1, T2, and T3. Samples were centrifuged at $1,300 \times g$ for $10 \mathrm{~min}$ at $5^{\circ} \mathrm{C}$. Aliquots of the serum were placed in microtubes and stored at $-20^{\circ} \mathrm{C}$. Analyses were performed using an automatic biochemical analyzer (Cobas Mira Plus, Roche, Basel, Switzerland). The hepatic enzyme profile included aspartate aminotransferase (AST), transaminase-glutamic pyruvate (GPT), gamma-glutamyl transferase (GGT), and alkaline phosphatase. Serum concentrations of total protein (PPT) and albumin (ALB) were also determined. The renal enzyme profile was based on the serum urea and creatinine concentrations. Globulin concentrations were calculated based on the difference between total protein (PPT) and albumin (ALB) values. Commercial kits (Biotécnica Indústria e Comércio Ltda, Varginha, MG, Brazil) were used. Plasma fibrinogen concentration (FIB) in the samples from the EDTA tubes was measured. Two capillary tubes containing each sample were centrifuged (CELM $\left.{ }^{\circledR}\right)$ at $1,300 \times g$ for 5 min. One of the capillary tubes was used for PPT evaluation. The remaining capillary tube was incubated for 3 min at $56^{\circ} \mathrm{C}$ for the denaturation of fibrinogen and centrifuged at 1,300 $\times g$ for 5 min for FIB analyses. FIB values were determined based on the difference between the readings obtained from the two capillary tubes in a Brix refractometer (Biobrix).

\section{Hematological analysis}

For hematological analysis, blood cells from each blood sample were counted to determine variations. Red blood cell analysis included erythrocyte counts, hemoglobin concentration, hematocrit, mean corpuscular volume, and mean corpuscular hemoglobin concentration. White blood cell (WBC) analysis included total and differential leukocyte counts. All hematological measurements were performed using a hematology analyzer (ABC VET; Horiba ABX S.A., Montpellier, France). Differential leukocyte counts were performed by optical microscopy (1,000×, Eclipse E200; Nikon, Tokyo, Japan) of blood smear slides stained with a Fast Panoptic kit (Romanovsky-based) (Laborclin, São José do Rio Preto, SP, Brazil). A total of 100 cells were counted per slide, and the percentage values of lymphocytes, neutrophils (segmented and rods), monocytes, eosinophils, and basophils were obtained. Cytomorphology was performed by identifying reactive lymphocytes, activated monocytes, and hypersegmented neutrophils.

\section{Immunophenotyping of $\mathrm{T}$ lymphocytes from peripheral blood}

To quantify the number of T cells (CD3+), flow cytometry was used to immunophenotype peripheral blood by subjecting $50 \mu \mathrm{L}$ of blood to fixation and permeabilization. For fixation, $2 \mathrm{~mL}$ of FACS lysing solution (FSL) (Becton Dickinson, San Diego, CA, USA) was added under intense agitation. Samples were then incubated for $7 \mathrm{~min}$ and centrifuged at $400 \times g$ for $7 \mathrm{~min}$ at room temperature (RT). The supernatant was discarded, and $2 \mathrm{~mL}$ of PBS-P (PBS containing 0.5\% BSA, $0.5 \%$ saponin, and 0.1\% sodium azide) was added and incubated for 10 min. Samples were centrifuged again at $400 \times g$ for $7 \mathrm{~min}$ at room temperature, and the supernatant was removed. The cells were resuspended and incubated with $2 \mu \mathrm{L}$ of monoclonal antibody anti-CD3 A647 (clone UCHT1; Biolegend, San Diego, CA, USA) for 30 min. After incubation, 3 mL of PBS was added under gentle stirring in a vortex and centrifuged at $400 \times g$ for $7 \mathrm{~min}$ at room temperature. This procedure was repeated after discarding the supernatant. Finally, cells were resuspended and fixed 
with $200 \mu \mathrm{L}$ of FACS fix solution (FFS) (10.0 g/L paraformaldehyde, $10.2 \mathrm{~g} / \mathrm{L}$ sodium cacodylate, and $6.65 \mathrm{~g} / \mathrm{L}$ sodium chloride, pH 7.2). Data acquisition (20,000 events) was performed using a FACSCalibur flow cytometer (Becton Dickinson) and analyzed using FlowJo software (TreeStar Inc., Ashland, OR, USA). Each assay included an internal control for autofluorescence, for which the cells were incubated in the presence of PBS containing 0.5\% BSA.

Each horse's leukocyte subpopulations were quantified based on size (forward scatter; FSC) and granularity (side scatter; SSC) properties which are commonly used to identify lymphocytes (FSC ${ }^{\text {low }}$ and SSC ${ }^{\text {low }}$ ) (Figure 1A, left). Lymphocytes were detected based on their characteristic

A

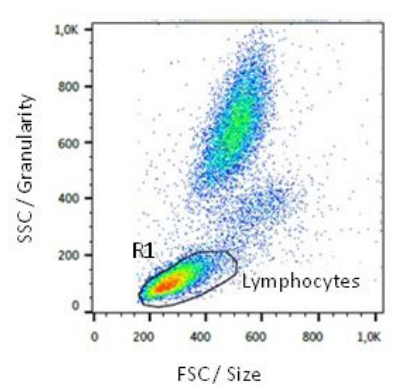

B
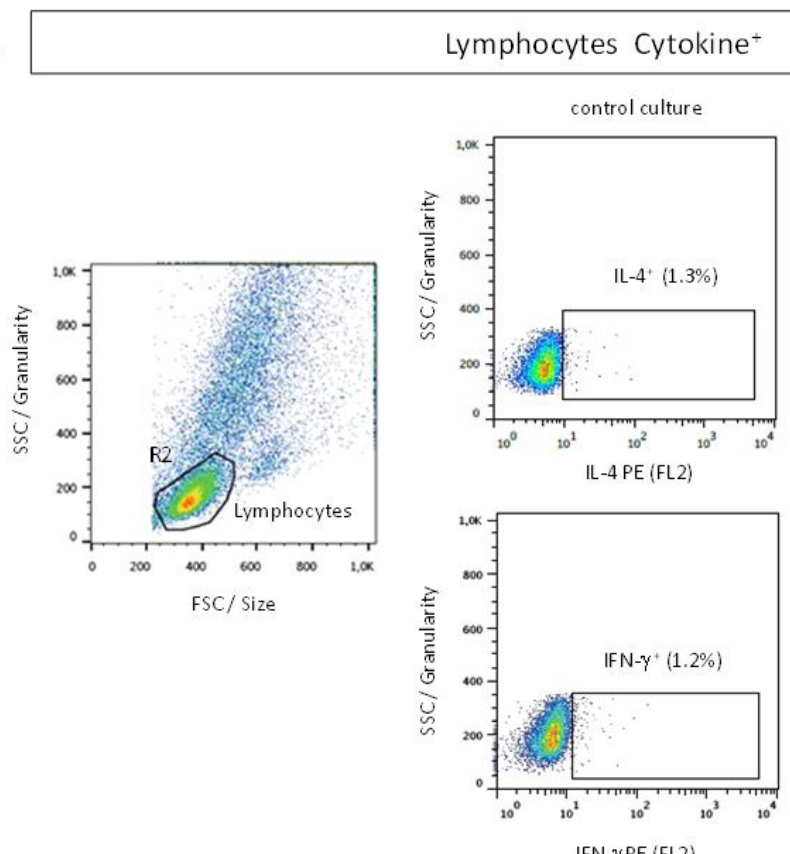

IFN-YPE (FL2)

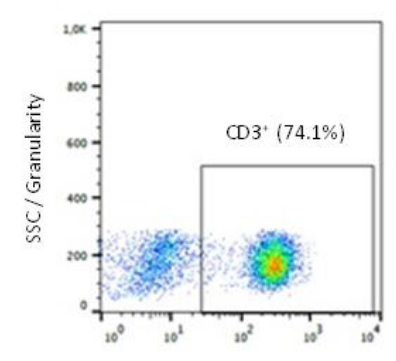

$\mathrm{CD} 3 \mathrm{~A} 647$ (FL4)

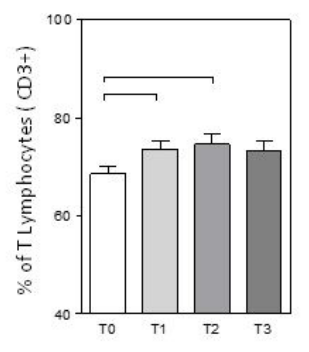

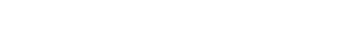
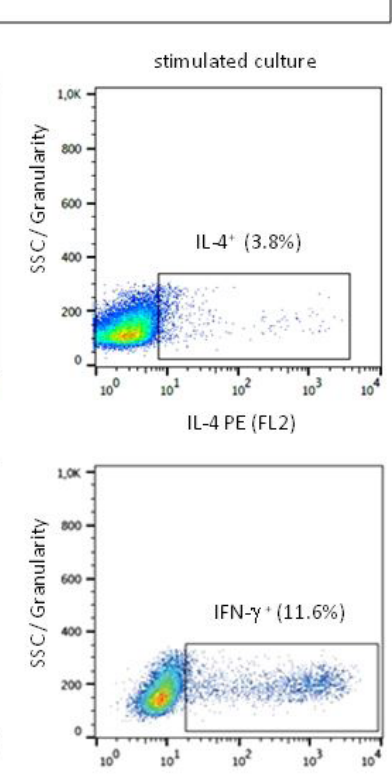

IFN-Y PE (FL2)

Figure 1. Representative dot plots illustrating the analysis of lymphocyte subpopulation (CD3+ cells) profiles and intracellular cytokine profiles in the lymphocytes of the peripheral blood samples of horses subjected to autohemotherapy. (A) left, figure representing the pseudocolor plot distribution of leucocytes from whole blood samples according to cell size (Forward scatter, FSC) versus granularity (Side scatter, SSC) used for lymphocyte gate selection (R1) of "FSC Low, SSC Low" events; center, figure representing the pseudocolor plot distribution of cells from the gate selection in (R1) according to SSC and antibody CD3A647 (FL4); right, bar graph showing the percentage of positive cells \pm S.E T Lymphocytes $\left(\mathrm{CD}^{+}\right)$. Significant differences $(p<0.05)$ are indicated by a connecting line between TO, T1, and T2; (B) right, pseudocolor plot distribution of horse whole-blood samples after culture was stimulated to represent FSC and SSC used for lymphocyte gate selection (R2) of "FSC Low SSC Low" events; center, pseudocolor plot distribution of cells from the gate selection in R2 according to SSC and anti-IL-4 and anti-IFN- $\gamma$ (upper and lower, respectively) in cells obtained from the control culture; right, pseudocolor plot distribution of cells to according to SSC and anti-IL-4 and anti-IFN- $\gamma$ (upper and lower, respectively) from cells obtained from the stimulated culture. The rectangles were used to select the cytokines ${ }^{+}$ cells to be expressed as percentages. 
FSC versus SSC gain distributions, and their phenotypic features were analyzed (CD3 ${ }^{+}$cells) on color graphs to evaluate their fluorescence spectra to create granularity SSC and CD3A647 dot plots (Figure 1A, middle). The results were expressed as the percentage of positive cells within the selected gate (Figure 1A, right).

\section{Culture}

Short-term whole blood cultures were performed to evaluate the presence of intracytoplasmic cytokines, using the methods previously reported by Moreira et al. (2015). Briefly, $1 \mathrm{~mL}$ blood samples were cultured in $1 \mathrm{~mL}$ RPMI medium (Invitrogen, Carlsbad, CA, USA) at $37^{\circ} \mathrm{C}$ and $5 \%$ $\mathrm{CO}_{2}$ for $4 \mathrm{~h}$. Blood was only incubated in the presence of RPMI (control culture) or with phorbol 12-myristate 13-acetate (PMA, 25 ng/mL; Sigma-Aldrich, St. Louis, MO, USA) and ionomycin $(1 \mu \mathrm{g} / \mathrm{mL}$, Sigma-Aldrich) (stimulate culture). Brefeldin A (BFA, $10 \mu \mathrm{g} / \mathrm{mL}$, Sigma-Aldrich) was added to the cultures to block cytokine secretion. After $4 \mathrm{~h}$ of incubation, cultures were treated with $2 \mathrm{mM}$ ethylenediaminetetraacetic acid (EDTA, Sigma-Aldrich) and maintained at room temperature for $15 \mathrm{~min}$.

\section{Intracellular cytokine immunostaining}

To evaluate the number of lymphocytes producing cytokines after short-term in vitro culture, the cells were immunostained. Erythrocytes were lysed using $6 \mathrm{~mL}$ of FLS and vortexed. After $5 \mathrm{~min}$, the suspension was centrifuged at $400 \times g$ for $7 \mathrm{~min}$ at room temperature. Samples were then incubated with FACS permeabilizing solution (FPS) for $7 \mathrm{~min}$ (0.015 M phosphate-buffered, supplemented with 0.5\% bovine serum albumin, 0.5\% saponin, and 0.1\% sodium azide; SigmaAldrich). The cell suspension was centrifuged again at $400 \times g$ for $7 \mathrm{~min}$ at room temperature. The cells were then resuspended in $0.5 \mathrm{~mL}$ FPS and a $50-\mu \mathrm{L}$ suspension and incubated with $1 \mu \mathrm{L}$ of monoclonal antibodies labeled with phycoerythrin (PE). Theses monoclonal antibody were previously tested and exhibited cross-reactivity against horse cytokines, including bovine anti-IFN- $\gamma$ (clone CC302), anti-IL-4 (clone CCO3), human anti-IL-6 (clone MQ2-13A5), anti-IL-8 (clone G2658), and anti-IL-10 (clone JES316T3). Cells were incubated in the dark (30 min, room temperature), washed once with FACS buffer $\left(400 \times g, 10 \mathrm{~min}, 4^{\circ} \mathrm{C}\right)$, and fixed with $200 \mu \mathrm{LFFS}$. Data acquisition (30,000 events) was performed using a FACSCalibur flow cytometer and analyzed using FlowJo software. Horse whole blood leukocytes were first identified based on their specific forward (FSC) and side (SSC) light scatter properties (Figure1B, left). Lymphocytes (R2) were selected based on their characteristic FSC versus SSC gain distribution. Intracytoplasmic cytokines were analyzed on color graphs to evaluate lymphocyte cytokines that were positive for granularity SSC and cytokine ${ }^{+} \mathrm{PE}$ - FL2 dot plots (Figure 1B). Results were expressed as percentages of positive cells, and the data were converted into indices, calculated as stimulated culture/control culture ratios.

\section{Comparative analysis of lymphocyte cytokines ${ }^{+}$from peripheral blood}

To evaluate the profile of intracytoplasmic cytokines, cytokine signatures were built according to the methods of Costa-Pereira et al. (2015). Intracellular cytokine indices from each animal subjected to AHT were calculated. Briefly, the "global median" value for each intracellular cytokine was calculated by collating all data ( $\mathrm{TO}+\mathrm{T} 1+\mathrm{T} 2+\mathrm{T} 3)$. The "global median" was used as the cut-off to tag each horse as displaying "Low" or "High" levels of intracellular cytokines as follows: IL-10 = 0.96; IL-4 = 1.59; IL-6 = 1.32; IL-8 = 1.03; and IFN- $\gamma=10.1$ (Figure 2A). After categorizing the horses as "Low" or "High" cytokine producers, the frequency was calculated using diagrams for each timeline (TO, T1, T2, and T3) (Figure 2B). The frequency of cytokines for each timeline was assessed to generate the TO, T1, T2, and T3 indices for cytokine signature radar charts (Figure 2C).

\section{Preparation of zymosan and labeling with Alexa fluor 647}

To evaluate neutrophil phagocytosis, Zymosan A particles were coated with Alexa Fluor 647. Zymosan A is a polysaccharide produced from the cell wall of Saccharomyces cerevisiae (Sigma-Aldrich) and used as a phagocytosable particle. Zymosan A was suspended at 1\% in 0.15 M sodium chloride and placed in a boiling water bath for $1 \mathrm{~h}$. The samples were then centrifuged at $1,844 \times g$ for $7 \mathrm{~min}$, and the supernatant was removed. The residue was then resuspended in RPMI. To label zymosan with Alexa Fluor 647 fluorochrome (A647, Thermo Fisher Scientific), 

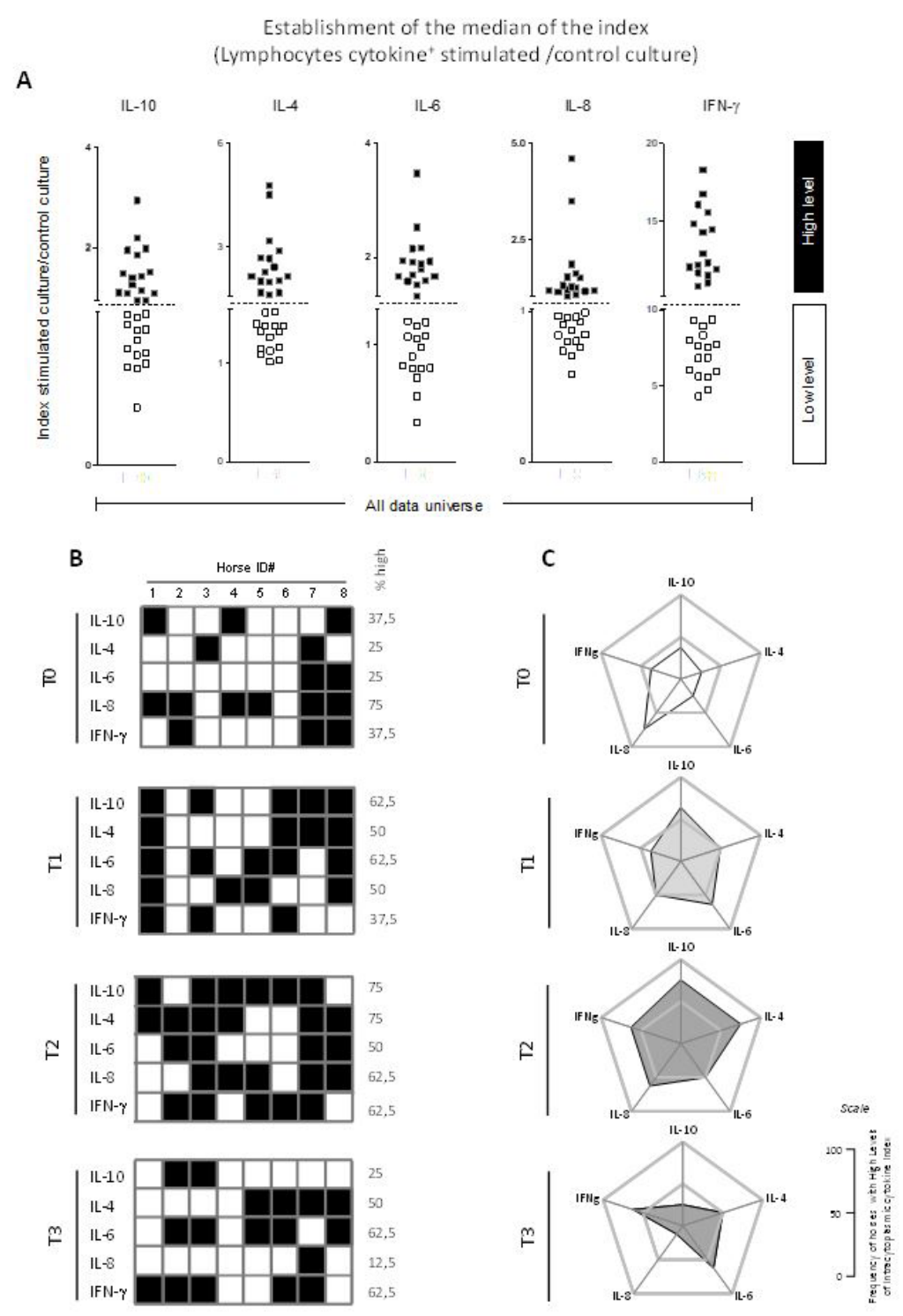

Figure 2. Signature analysis of the intracytoplasmic cytokines in lymphocytes from peripheral blood samples of the horses submitted to autohemotherapy (AHT) after the cells were cultured in vitro under PMA stimulation. (A) Representative scatter graphs employed to establish global median cut-off edges of the indices (Lymphocyte's cytokine $^{+}$stimulated/control culture) of each cytokine (IL-10, IL-4, IL-6, IL-8, and IFN- $\gamma$ ) used to segregate

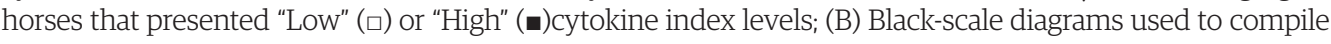
the frequency (\%) of high cytokine producers. (C) Radar chart graph with cytokine indices for each occurrence after AHT (TO, T1, T2, and T3). "High cytokine producers" were considered relevant when frequencies were above the 50th percentile. The results are expressed as the proportion of horses with plasmatic cytokine levels above the global median.

$300 \mu \mathrm{L}$ of zymosan, containing $200 \times 10^{6}$ particles/mL, was transferred to a 2 -mL microtube with a conical bottom containing $15 \mu \mathrm{L}$ of A647 $(1 \mathrm{mg} / \mathrm{mL})$. The cells were incubated for $30 \mathrm{~min}$ at room temperature. After incubation, $2 \mathrm{~mL}$ of PBS was added, and the mixture was centrifuged at $1,844 \times g$ for $7 \mathrm{~min}$ at room temperature. Subsequently, the supernatant was discarded, and the pellet was resuspended and washed under the same conditions as before. The particles were then resuspended in PBS at a final concentration of $250 \times 10^{6}$ particles $/ \mathrm{mL}$ and stored at $8^{\circ} \mathrm{C}$ until use.

\section{Neutrophil phagocytic activity}

To evaluate the phagocytic activity of neutrophils, the prepared Zymosan A particles were incubated with short-term in vitro cultures of whole blood. After counting the total number of 
leukocytes in each sample, heparinized peripheral blood was centrifuged at $400 \times g$ for $10 \mathrm{~min}$. The plasma was removed, and the concentration was adjusted to $5 \times 10^{6}$ leukocytes $/ \mathrm{mL}$. Of this blood suspension, $1 \mathrm{~mL}$ was transferred to polypropylene conical tubes (14 mL), and $40 \mu \mathrm{L}$ Zymosan-A647 (10 x $10^{6}$ particles) and $960 \mu \mathrm{L}$ RPMI medium were added. After a 2 h incubation at $37^{\circ} \mathrm{C}$ and $5 \% \mathrm{CO}_{2}$, the samples were centrifuged at $400 \times g$ for $7 \mathrm{~min}$ at room temperature. Erythrocyte lysis was performed by adding $5 \mathrm{mLFLS}$ to the samples while vortexing and samples were incubated for $5 \mathrm{~min}$ at room temperature. The samples were then centrifuged again at $400 \times g$ for $7 \mathrm{~min}$, and the supernatant was discarded. The remaining cells were resuspended in $4 \mathrm{~mL}$ PBS. The samples were then centrifuged again at $400 \times g$ for $7 \mathrm{~min}$ and resuspended in $300 \mu \mathrm{L}$ of FFS. Data acquisition was performed using a FACSCalibur flow cytometer by evaluating 50,000 events. FlowJo software (Beckton, Dickinson \& Company) was used for the analysis. Leukocytes were first identified based on their FSC and SSC light scatter properties (Figure 3A). Following FSC versus SSC gain adjustments, neutrophils (R1) were selected, and their phagocytic activity was analyzed on graphs to evaluate their fluorescence spectra to Zymosan A647 versus Size-FSC dot plots (Figure 3B). The results were expressed as the percentage of positive neutrophils Zymosan+A647 within the selected gate (Figure 3C).

\section{Phagocytic activity of the neutrophils of the peripheral blood from horses}

A

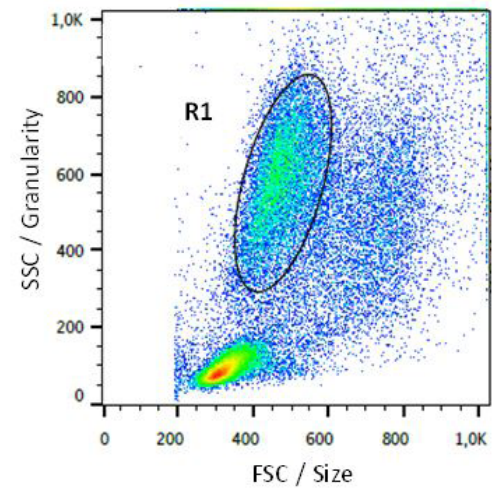

C

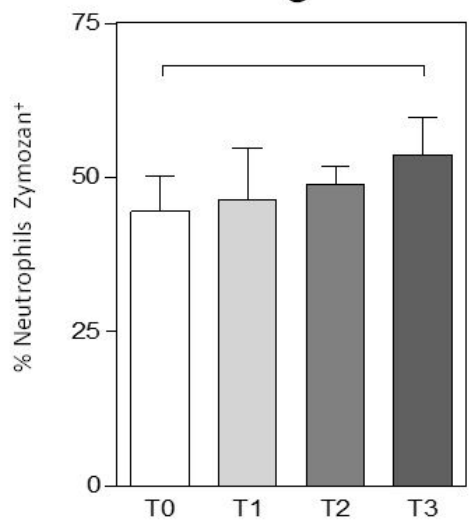

B

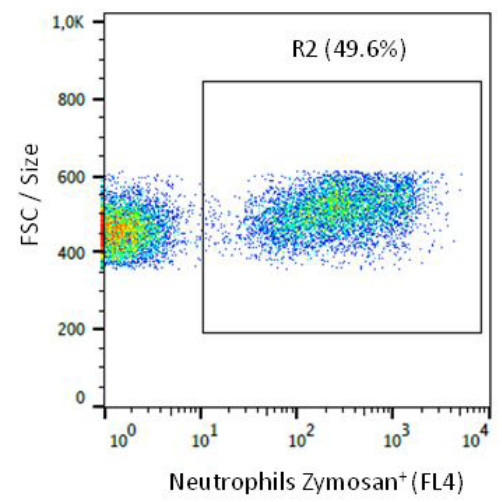

D

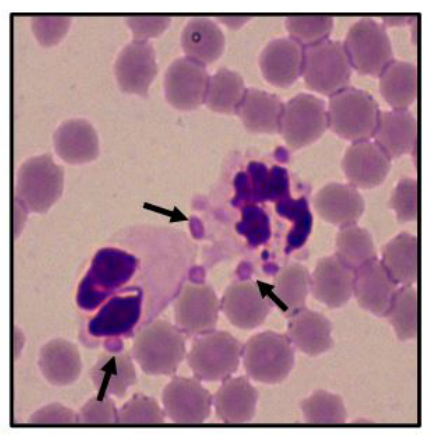

Figure 3. Phagocytic neutrophil activity in horses submitted the autohemotherapy. Flow cytometry procedures were performed to determine the phagocytic capacity of neutrophils. (A) pseudocolor plot distribution of neutrophils from the gate selection in (R1); (B) percentage of neutrophils (Zymozan+) determined by square gate (R2) statistics applied on Size (FSC) versus Zymosan+ neutrophil (FL4) dot-plot distributions; (C) graphic bar indicating the percentage of Zymozan ${ }^{+}$neutrophils throughout the trial; TO refers to the analysis before autohemotherapy, T1, T2, and T3 were performed $3 \mathrm{~d}$ after the first, second, and third administration of AHT, respectively. Significant differences $(p<0.05)$ are indicated by a connecting line; (D) neutrophils phagocytizing the zymosan (arrow). 


\section{Statistical analysis}

Statistical analysis was performed using GraphPad Prism 5.03 software (San Diego, CA, USA). Data analysis was conducted using an analysis of variance (ANOVA) test, followed by Tukey's or Wilcoxon post-hoc multiple comparison tests for parametric and non-parametric data, respectively, to evaluate the data obtained before (TO) and after (T1, T2, and T3) AHT. Differences were considered significant at $p<0.05$. Intracellular cytokine signatures were assembled as described by the methods of Costa-Pereira et al. (2015). For this approach, the global median values of each cytokine were used as a threshold to categorize subjects as having "Low" or "High" levels of intracellular cytokines.

\section{Results and discussion}

\section{AHT did not affect most clinical parameters}

Following the AHT procedures, the horses did not show any damage or injury at the application sites during the experiment. No significant changes were observed in clinical parameters, including heartbeat, breathing rate, CRT, and rectal temperature (Table 1).

Table 1. Clinical parameters of the horses submitted to autohemotherapy over time.

\begin{tabular}{cccccc}
\hline & Reference & \multicolumn{4}{c}{ Autohemotherapy (AHT) } \\
\cline { 3 - 6 } Clinical parameters & range & T0 & T1 & T2 & T3 \\
\hline Heartbeat $(b p m)$ & $28-40$ & $43.13( \pm 6.0)$ & $39.0^{\text {ad }}( \pm 4.4)$ & $39.73^{\text {ad }}( \pm 3.7)$ & $42.6( \pm 5.1)$ \\
Breathing rate $(\mathrm{bpm})$ & $8-20$ & $26.5( \pm 7.4)$ & $25.63( \pm 6.8)$ & $24.8( \pm 5.6)$ & $26.26( \pm 5.9)$ \\
Capillary refill time $(\mathrm{CRT})$ & $<2$ & $<2$ & $<2$ & $<2$ & $<2$ \\
Rectal temperature $\left({ }^{\circ} \mathrm{C}\right)$ & $37-38$ & $37.79( \pm 0.3)$ & $37.49( \pm 0.5)$ & $37.38( \pm 0.4)$ & $37.47( \pm 0.3)$ \\
\hline
\end{tabular}

Mean ( \pm standard error) values of the clinical parameters of horses TO to refer to the analysis before AHT and T1, T2, and T3 were performed $3 \mathrm{~d}$ after the first, second, and third administrations of AHT, respectively; ; d, Represent significantly different values $(p<0.05)$ between TO and T3. Reference values (Speirs, 1997).

\section{AHT slightly affected biochemical parameters}

No significant alterations were detected in biochemical parameters, except for an increasein globulin at T3 (Table 2). Benesi et al. (2009) reported that AST, AP, and GGT levels in Brazilian thoroughbred horses varied according to age. Here, those variations were not detected owing to our short test period (3 weeks) and low age variation (2 to 4 years). AHT did not lead to any significant changes in AST; as AST is the best indicator of liver injury (Lopes, 2016), this result reinforces the safety of AHT.

\section{Horses subjected to AHT displayed changes in reactive lymphocytes, monocytes, and eosinophils}

Unlike clinical and biochemical parameters, hemograms were affected by AHT. An increase in reactive lymphocytes and eosinophils was observed, whereas a decrease in monocytes was detected at T2 and T3 (Table 3). No significant changes were observed in any of the other remaining cells. Our results agree with those of Moraes and Ota (2017), where hematological analysis after AHT did not present significant differences in most parameters. In the present study, a decrease in monocytes was observed over time, which might have been due to monocyte migration to the injection site or other organs/tissues, as has been reported (Mueller \& Petterson, 1926; Teixeira, 1940). Regarding eosinophils, it has been shown that AHT benefits allergenic processes, albeit transiently (Tizard, 2008; Lopes, 2016). When an increase in eosinophils is noted, the removal of large extracellular parasites can be promoted; however, eosinophilia cannot be considered when eosinophil numbers remain within the reference range. This profile was also observed in the present study, and similar observations have been reported by Gomes et al. (2014). Reactive lymphocyte counts also increased after the second week of AHT. This finding is significant as it demonstrates the participation of lymphocytes as a result of AHT. Altogether, these data indicate that minor variations in some parameters and cells were observed after AHT. 
Table 2. Biochemical analysis of the horses submitted to Autohemotherapy over time.

\begin{tabular}{|c|c|c|c|c|c|}
\hline \multirow{2}{*}{ Biochemical Analysis } & \multirow{2}{*}{ Reference range } & \multicolumn{4}{|c|}{ Autohemotherapy } \\
\hline & & TO & T1 & $\mathrm{T} 2$ & T3 \\
\hline \multirow{2}{*}{ AST (U/L) } & \multirow{2}{*}{$226-366$} & 199.37 & 207.75 & 206 & 213.50 \\
\hline & & $( \pm 30.4)$ & $( \pm 31.11)$ & $( \pm 22.3)$ & $( \pm 32.35)$ \\
\hline \multirow{2}{*}{ GPT (U/L) } & \multirow{2}{*}{$3-23$} & 26.78 & 34.78 & 34.69 & 27.69 \\
\hline & & $( \pm 12.48)$ & $( \pm 30.4)$ & $( \pm 11.76)$ & $( \pm 12.17)$ \\
\hline \multirow{2}{*}{ GGT (U/L) } & \multirow{2}{*}{$6-32$} & 30.70 & 30.87 & 31.39 & 29.67 \\
\hline & & $( \pm 3.88)$ & $( \pm 3.21)$ & $( \pm 3.6)$ & $( \pm 3.3)$ \\
\hline \multirow{2}{*}{$\mathrm{AP}(\mathrm{U} / \mathrm{L})$} & \multirow{2}{*}{$86-295$} & 329.37 & 336 & 327 & 332.37 \\
\hline & & $( \pm 47.84)$ & $( \pm 48.19)$ & $( \pm 67.61)$ & $( \pm 45.64)$ \\
\hline \multirow{2}{*}{ Urea (mg/dL) } & \multirow{2}{*}{ 21.4-51.5 } & 30.04 & 31.24 & 30.91 & 33.77 \\
\hline & & $( \pm 2.84)$ & $( \pm 3.94)$ & $( \pm 3.95)$ & $( \pm 4.09)$ \\
\hline \multirow{2}{*}{ Creatinine (mg/dL) } & \multirow{2}{*}{$0.4-2.2$} & 0.95 & 0.90 & 1.06 & 0.85 \\
\hline & & $( \pm 0.09)$ & $( \pm 0.13)$ & $( \pm 0.85)$ & $( \pm 0.16)$ \\
\hline \multirow{2}{*}{ Total protein (g/dL) } & \multirow{2}{*}{$6-8$} & 6.36 & 6.46 & 6.37 & 6.72 \\
\hline & & $( \pm 0.45)$ & $( \pm 0.27)$ & $( \pm 0.40)$ & $( \pm 0.27)$ \\
\hline \multirow{2}{*}{ Albumin (g/dL) } & \multirow{2}{*}{$2.4-4.1$} & 3.55 & 3.56 & 3.47 & 3.52 \\
\hline & & $( \pm 0.39)$ & $( \pm 0.33)$ & $( \pm 0.22)$ & $( \pm 0.40)$ \\
\hline \multirow{2}{*}{ Globulin (g/dL) } & \multirow{2}{*}{$2.6-4.0$} & 2.80 & 2.89 & 2.89 & $3.19^{\mathrm{a}}$ \\
\hline & & $( \pm 0.61)$ & $( \pm 0.50)$ & $( \pm 0.53)$ & $( \pm 0.54)$ \\
\hline \multirow{2}{*}{ Proportion A:G } & \multirow{2}{*}{ 0.6-0.9 } & 1.36 & 1.28 & 1.25 & 1.14 \\
\hline & & $( \pm 0.55)$ & $( \pm 0.35)$ & $( \pm 0.36)$ & $( \pm 0.31)$ \\
\hline \multirow{2}{*}{ Fibrinogen (mg/dL) } & \multirow{2}{*}{$0-400$} & 150 & 100 & 100 & 75 \\
\hline & & $( \pm 207)$ & $( \pm 151)$ & $( \pm 106)$ & $( \pm 148)$ \\
\hline
\end{tabular}

Mean ( \pm standard error) values of biochemical analysis of horses administered autohemotherapy (AHT). TO to refer to the analysis before $A H T$, and $T 1, T 2$, and $T 3$ were performed $3 \mathrm{~d}$ after the first, second, and third $A H T$, respectively. a,b,c,dRepresents significantly different values $(p<0.05)$ between TO, T1, T2, and T3. AST, aspartate aminotransferase; GPT, glutamate-pyruvate transaminase; GGT, gamma-glutamyl transferase; AP, alkaline phosphatase; A, albumin; G, globulin. Reference values (Kaneko et al., 1997; Latimer, 2003).

\section{AHT induced an increase of T Lymphocytes in the peripheral blood and cytokine} production by these cells after stimulation in vitro

Specific monoclonal antibodies against equine cell subsets and cytokines are scarce or commercially unavailable. For this reason, bovine and/or human CD3+ cell markers (Tlymphocytes) that cross-react with horses were used in this study (Araújo, personal communication). Agreeing with previous data (Table 3), T lymphocytes (CD3+cells) increased after AHT at T1 and T2 (Figure1A). After AHT, an increase in the Tlymphocyte population was also followed by an increase in cytokine production. Cytokine production indices varied with time (Figures $2 \mathrm{~B}$ and $2 \mathrm{C}$ ). In general, most cytokines increased (IL-6, IL-10 IFN- $\gamma$, IL-4), while one (IL-8) decreased (Figure 2B and 2C). Based on the radar chart areas, most cytokines increased at $\mathrm{T} 1$ and $\mathrm{T} 2$ before returning to baseline levels at T3 (Figure 2C); however, IL-8 levels did not return to baseline levels and remained low. IL-8 induces chemotaxis in neutrophils and other granulocytes to the site of infection and stimulates phagocytosis (Baggiolini \& Clark-Lewis, 1992). In summary, our data demonstrated that the induction of most cytokines peaked at T2 and reverted to baseline levels at T3. This immunological stimulus in horses suggests that AHT can be used as a complementary therapy.

\section{Neutrophil phagocytic activity in peripheral blood increased after AHT}

Our data indicated that ATH induced an increase in the phagocytic activity of neutrophils at T3 (Figure 3C), illustrated by the occurrence of stained neutrophils containing zymosan 
Table 3. Hematological blood tests and reference ranges in horses submitted to autohemotherapy over time.

\begin{tabular}{|c|c|c|c|c|c|}
\hline \multirow{2}{*}{ Hematological Analysis } & \multirow{2}{*}{ Reference range } & \multicolumn{4}{|c|}{ Autohemotherapy } \\
\hline & & TO & T1 & $\mathrm{T} 2$ & T3 \\
\hline \multirow{2}{*}{ Erythrocytes (x10 ${ }^{6}$ cells/ $\left.\mu \mathrm{L}\right)$} & \multirow{2}{*}{$6.4-10.0$} & 5.47 & 5.58 & 5.67 & 5.77 \\
\hline & & $( \pm 0.52)$ & $( \pm 0.76)$ & $( \pm 0.63)$ & $( \pm 0.57)$ \\
\hline \multirow{2}{*}{ Hemoglobin (g/dL) } & \multirow{2}{*}{$11-17$} & 9.18 & 9.10 & 9.10 & 9.76 \\
\hline & & $( \pm 1.84)$ & $( \pm 1.35)$ & $( \pm 1.0)$ & $( \pm 1.34)$ \\
\hline \multirow{2}{*}{ WBC (cells/ $\mu \mathrm{L}$ ) } & \multirow{2}{*}{$5.200-13.900$} & 7.85 & 7.60 & 7.52 & 7.36 \\
\hline & & $( \pm 0.84)$ & $( \pm 1.62)$ & $( \pm 1.43)$ & $( \pm 1.02)$ \\
\hline \multirow{2}{*}{ Lymphocytes $\left(\mathrm{mm}^{3}\right)$} & \multirow{2}{*}{$1.500-7.700$} & 3.831 & 4.030 & 3.540 & 3.383 \\
\hline & & $( \pm 970)$ & $( \pm 1.207)$ & $( \pm 817)$ & $( \pm 630)$ \\
\hline \multirow{2}{*}{ Reactive lymphocytes $\left(\mathrm{mm}^{3}\right)$} & \multirow{2}{*}{---} & 0.5 & 0.25 & $2.37^{a b}$ & $2.62^{\mathrm{ab}}$ \\
\hline & & $( \pm 0.92)$ & $( \pm 0.70)$ & $( \pm 1.59)$ & $( \pm 1.68)$ \\
\hline \multirow{2}{*}{$\begin{array}{l}\text { Segmented neutrophils } \\
\qquad\left(\mathrm{mm}^{3}\right)\end{array}$} & \multirow{2}{*}{$2.200-8.500$} & 3.545 & 3.019 & 3.382 & 3.250 \\
\hline & & $( \pm 614)$ & $( \pm 735)$ & $( \pm 1.065)$ & $( \pm 705)$ \\
\hline \multirow{2}{*}{ Band neutrophils $\left(\mathrm{mm}^{3}\right)$} & \multirow{2}{*}{$0-100$} & 37.5 & 64.2 & 72.8 & 27.5 \\
\hline & & $( \pm 40)$ & $( \pm 82)$ & $( \pm 87)$ & $( \pm 52)$ \\
\hline \multirow{2}{*}{ Monocytes (mm³) } & \multirow{2}{*}{$100-1000$} & 302 & 210 & $94^{\mathrm{ab}}$ & $120^{\mathrm{ab}}$ \\
\hline & & $( \pm 204)$ & $( \pm 218)$ & $( \pm \mathbf{8 8 )}$ & $( \pm 83)$ \\
\hline \multirow{2}{*}{ Eosinophils (mm³) } & \multirow{2}{*}{$100-1000$} & 104 & 243 & $280^{\mathrm{a}}$ & $368^{a}$ \\
\hline & & $( \pm 103)$ & $( \pm 119)$ & $( \pm 219)$ & $( \pm 282)$ \\
\hline \multirow{2}{*}{ Basophils $\left(\mathrm{mm}^{3}\right)$} & \multirow{2}{*}{$0-290$} & 75 & 26 & 16 & 8 \\
\hline & & $( \pm 104)$ & $( \pm 36)$ & $( \pm 30)$ & $( \pm 23)$ \\
\hline \multirow{2}{*}{ Platelets $\left(\mathrm{x} 10^{3} / \mu \mathrm{L}\right)$} & \multirow{2}{*}{$100-308$} & 224.50 & 241 & 241.50 & 220.50 \\
\hline & & $( \pm 123)$ & $( \pm 136)$ & $( \pm 48)$ & $( \pm 51)$ \\
\hline
\end{tabular}

Mean ( \pm standard error) values of hematological hose blood samples. TO refers to the analysis before the autohemotherapy (AHT), and $\mathrm{T} 1, \mathrm{~T} 2$, and $\mathrm{T} 3$ were performed $3 \mathrm{~d}$ after the first, second, and third administrations of the AHT, respectively. ab. Represents significantly different values $(p<0.05)$ between TO and T1. Reference values (Jain, 1993; Meyer et al., 1995).

(Figure 3D). Polymorphonuclear neutrophils have been shown to play an important role against many pathogens, including bacteria, fungi, and protozoa (Mortaz et al., 2018; Vanderstock et al., 2018). Consistent with these observations, lower neutrophil blood counts are related to a higher propensity to develop pneumonia in foals (Chaffin et al., 2004). Neutrophils can migrate through blood vessels and interstitial tissues by chemotaxis induced by IL-8, C5a, and LTB4 (Yoo et al., 2011). Considering that phagocytic activity plays a vital role in immune responses, our data suggest that AHT could be an alternative treatment against infectious diseases (e.g., herpes) (Olwin et al., 1997). These preliminary data should encourage further studies on AHT as an alternative, complementary, and low-cost therapy for some pathologies, especially those related to infectious diseases.

\section{Conclusions}

AHT was shown to be a safe procedure that did not affect most clinical parameters of healthy horses. AHT also transiently induced the activation of the immune response, increasing lymphocyte population, cytokine production, and neutrophil phagocytosis.

\section{Acknowledgements}

This work was financially supported by Coordenadoria de Aperfeiçoamento de Pessoal de Nível Superior (CAPES), Conselho Nacional de Desenvolvimento Científico e Tecnológico 
(CNPq), Fundação de Amparo a Pesquisa do Estado de Minas Gerais (FAPEMIG), and Fundação de Apoio Ensino Pesquisa e Extensão (FEPE). Authors MSSA, OAMF, and RPS have received CNPq fellowships. The authors thank the program for the technological development of tools for health-FIOCRUZ and for the use of the flow cytometry platform.

\section{Ethics statement}

All procedures in this study were according to the guidelines set by the Brazilian Animal Experimental College (COBEA) and this study was approved by the Ethical Committee for the use of Experimental Animals (CETEA) of the UFMG, protocol NO 351/2017.

\section{Financial support}

This work was financially supported by Coordenadoria de Aperfeiçoamento de Pessoal de Nível Superior (CAPES), Conselho Nacional de Desenvolvimento Científico e Tecnológico (CNPq), Fundação de Amparo a Pesquisa do Estado de Minas Gerais (FAPEMIG) and Fundação de Apoio Ensino Pesquisa e Extensão (FEPE). MSSA, OAMF and RPS are CNPq fellowships. The authors thank the program for technological development in tools for health-FIOCRUZ for the use of Flow Cytometry Platform.

\section{Conflict of interests}

The authors declare that they have no known competing financial interests or personal relationships that could have appeared to influence the work reported in this paper.

\section{Authors' contributions}

PRL, MSP, RPS, OAMF and MSSA participated in the design of the study, the statistical analysis, and drafting or revising the manuscript. PRL, MAB, FOPL, JGO, RPAM, RRW and MSSA participated in obtaining the samples and conducting the experiments. All authors read and approved the final manuscript.

\section{Availability of complementary results}

The authors declare that readers' access to complementary information will be available upon request.

Place where the study was conducted: The animals were maintained in the Veterinary Hospital of the Universidade Federal de Minas Gerais, Belo Horizonte, Minas Gerais, Brazil. The experimental procedures were done in the Instituto Rene Rachou FIOCRUZ-MG

\section{References}

Baggiolini, M., \& Clark-Lewis, I. (1992). Interleukin-8, a chemotactic and inflammatory cytokine. FEBS Letters, 307(1), 97-101. http://dx.doi.org/10.1016/0014-5793(92)80909-Z. PMid:1639201.

Barnabé Escodro, P., Joaquim, J. G. F., Mariz, T. M. A., Oliveira, A. S., Escodro, L. O., Santos Filho, E. N., Ferreira Junior, J. V. T., \& Bernardo, J. O. (2012). Autohemotherapy at acupunture points post orchiectomy surgery in cart horses - eight cases report. Veterinária e Zootecnia, 4(19), 502-506.

Benesi, F. J., Howard, D. L., Leal, M. L. R., Gacek, F., Souza, J. A. T., \& Fernandes, W. R. (2009). Perfil bioquímico de algumas enzimas no plasma de potras da raça Brasileiro de Hipismo (BH) criadas em Colina, estado de São Paulo. Brazilian Journal of Veterinary Research and Animal Science, 46(4), 288-295. http://dx.doi.org/10.11606/ issn.1678-4456.bjvras.2009.26777.

Borges, O. M. M., Souza, A. P., Souza Mendes, R., Araújo, K. N., Torres, L. M., \& Dantas, A. K. F. P. (2014). Clinical Effectiveness of Autohemotherapy as an adjunct treatment of canine parvovirus. Acta Scientiae Veterinariae, 42, 1-7. http://www.ufrgs.br/actavet/42/PUB\%201224.pdf

Brewer, D. D. (2014). A systematic review of autohemotherapy as a treatment for urticaria and eczema. Cureus, 6(12), e233. http://dx.doi.org/10.7759/cureus.233.

Chaffin, M. K., Cohen, N. D., Martens, R. J., Edwards, R. F., Nevill, M., \& Smith 3rd, R. (2004). Hematologic and immunophenotypic factors associated with development of Rhodococcus equineumonia of foals at equine breeding farms with endemic infection. Veterinary Immunology and Immunopathology, 100(1-2), 33-48. http:// dx.doi.org/10.1016/j.vetimm.2004.02.010. PMid:15182994. 
Costa-Pereira, C., Moreira, M. L., Soares, R. P., Marteleto, B. H., Ribeiro, V. M., França-Dias, M. H., Cardoso, L. M., Viana, K. F., Giunchetti, R. C., Martins-Filho, O. A., \& Araújo, M. S. (2015). One-year timeline kinetics of cytokinemediated cellular immunity in dogs vaccinated against visceral leishmaniasis. BMC Veterinary Research, 11(1), 92. http://dx.doi.org/10.1186/s12917-015-0397-6. PMid:25880646.

Gomes, V. C. L., Moreira, F. M., Rezende, J. V., Ribeiro, A. A. R., Victor, R. M., Leme, F. O. P., Maranhão, R. P. A., Silva Filho, J. M., \& Palhares, M. S. (2014). Auto-hemoterapia como tratamento auxiliar para melanocitoma em equino: relato de caso. In Anais da XV Conferência Anual ABRAVEQ: Programas e Resumos (Trab. 235). Ribeirão Preto: ABRAVEQ.

Jain, N. C. (1993). Essentials of veterinary hematology (1. ed., p. 100-132). Philadelphia : Lea \& Febiger.

Kaneko, J. J., Harvey, J. W., \& Bruss, M. L. (1997). Clinical biochemistry of domestic animals (pp. 130-145). San Diego: Academic Press.

Latimer, K. S. (2003). Duncan and Prasse's veterinary laboratory medicine: clinical pathology (5th ed., pp. 70-82). New York: Wiley-Blackwell.

Lopes, P. (2016). Auto-hemoterapia no tratamento de dermatose em equino: relato de caso. [Trabalho de Conclusão de Residência, Universidade Federal de Minas Gerais, Escola de Veterinária]. Belo Horizonte.

Mettenleiter, M. W. (1936). Autohemotransfusion in preveting postoperative lung complications. American Journal of Surgery, 32(2), 321-323. http://dx.doi.org/10.1016/S0002-9610(36)90155-1.

Meyer, D. J., Coles, E. H., \& Rich, L. J. (1995). Medicina de laboratório veterinário (1. ed. pp. 23-36). São Paulo: Roca.

Moraes, M. R., \& Ota, C. C. C. (2017). Estudo científico da auto-hemoterapia. Curitiba: Universidade Tuiuti do Paraná. http://tcconline.utp.br/?tag=mirian-regina-de-moraes

Moreira, M. L., Dorneles, E. M., Soares, R. P., Magalhães, C. P., Costa-Pereira, C., Lage, A. P., Teixeira-Carvalho, A., Martins-Filho, O. A., \& Araújo, M. S. (2015). Cross-reactivity of commercially available anti-human monoclonal antibodies with canine cytokines: Establishment of a reliable panel to detect the functional profile of peripheral blood lymphocytes by intracytoplasmic staining. Acta Veterinaria Scandinavica, 57(1), 51. http:// dx.doi.org/10.1186/s13028-015-0142-y. PMid:26362860.

Moreno-Fernández, A., Macías-García, L., Valverde-Moreno, R., Ortiz, T., Fernández-Rodríguez, A., Moliní-Estrada, A., \& De-Miguel, M. (2019). Autohemotherapy with ozone as a possible effective treatment for fibromyalgia. Acta Reumatologica Portuguesa, 44(3), 244-249.

Mortaz, E., Alipoor, S. D., Adcock, I. M., Mumby, S., \& Koenderman, L. (2018). Update on neutrophil function in severe inflammation. Frontiers in Immunology, 9, 2171. http://dx.doi.org/10.3389/fimmu.2018.02171. PMid:30356867.

Mueller, E. F., \& Petterson, W. (1926). The mechanism of insulin action. Archives of Internal Medicine, 37(4), 512540. http://dx.doi.org/10.1001/archinte.1926.00120220062004.

Olwin, J. H., Ratajczak, H. V., \& House, R. V. (1997). Successful treatment of herpetic infections by autohemotherapy. Journal of Alternative and Complementary Medicine, 3(2), 155-158. http://dx.doi.org/10.1089/acm.1997.3.155. PMid:9395705.

Ravaut, P. (1913). Essai sur l'autohematotherapie dans quelques dermatoses. Annales de Dermatologie et de Syphiligraphie, 4, 292-296.

Santin, A. P. I., \& Brito, L. A. B. (2004). Estudo da papilomatose cutânea em bovinos leiteiros: Comparação de diferentes tratamentos. Ciência Animal Brasileira, 5(1), 39-45.

Sheikhi, A., Azarbeig, M., \& Karimi, H. (2014). Autohemotherapy in chronic urticaria: what could be the autoreactive factors and curative mechanisms? Annals of Dermatology, 26(4), 526. http://dx.doi.org/10.5021/ ad.2014.26.4.526. PMid:25143689.

Speirs, V. C. (1997). Exame clínico de equinos (365 p.). Porto Alegre: Artes Médicas.

Spiethoff, B. (1913). Therapeutischen Verwendung des Eigenserums (article in German). Munchener Medizinische Wochenschrift, 60, 521.

Teixeira, J. (1940). Complicações pulmonares pós-operatórias. Revista Brasil-Cirúrgico, 2, 213-230. http://www. rnsites.com.br/artigo_jesse_teixeira.pdf

Thomassian, A. (2005). Enfermidades dos cavalos (4. ed., pp. 42-43). São Paulo: Varela.

Tizard, I. R. (2008). Linfócitos Tauxiliares e sua resposta aos antígenos. In I. R. Tizard(Ed.), Imunologia veterinária, uma introdução (8. ed., pp. 143-155). Rio de Janeiro: Elsevier.

Trevisanil, A. C., Hermes-Uliana, C., Obikawa, C. Y., Nishitani, E. T., Bolonhez, A. L., \& Aristides, S. M. A. (2015). Análise dos níveis de imunoglobulinas séricas e monócitos de pacientes em tratamento com auto-hemoterapia. Arquivos de Ciências da Saúde da UNIPAR, 19(2), 101-107. http://dx.doi.org/10.25110/arqsaude.v19i2.2015.5430.

Tylicki, L., Niewȩgłowski, T., Biedunkiewicz, B., Burakowski, S., \& Rutkowski, B. (2001). Beneficial clinical effects of ozonated autohemotherapy in chronically dialysed patients with atherosclerotic ischemia of the lower limbs: Pilot study. The International Journal of Artificial Organs, 24(2), 79-82. http://dx.doi.org/10.1177/03913 9880102400204. PMid:11256512.

Vanderstock, J. M., Lecours, M. P., Lavoie-Lamoureux, A., Gottschalk, M., Segura, M., Lavoie, J. P., \& Jean, D. (2018). Phagocytosis, bacterial killing, and cytokine activation of circulating blood neutrophils in horses with severe equine asthma and control horses. American Journal of Veterinary Research, 79(4), 455-464. http://dx.doi. org/10.2460/ajvr.79.4.455. PMid:29583047. 
Webster, G. J. M., Hallett, R., Whalley, S. A., Meltzer, M., Balogun, K., Brown, D., Farrington, C. P., Sharma, S., Hamilton, G., Farrow, S. C., Ramsay, M. E., Teo, C.-G., \& Dusheiko, G. M. (2000). Molecular epidemiology of a large outbreak of hepatitis B linked to autohaemotherapy. Lancet, 356(9227), 379-384. http://dx.doi.org/10.1016/ S0140-6736(00)02529-0.

Yoo, S. K., Starnes, T. W., Deng, Q., \& Huttenlocher, A. (2011). Lyn is a redox sensor that mediates leukocyte wound attraction in vivo. Nature, 480(7375), 109-112. http://dx.doi.org/10.1038/nature10632. PMid:22101434. 